\title{
COMPUTATIONAL FLUID DYNAMICS (CFD) AND IT'S USE FOR ANALYSIS OF GAS DISTRIBUTION INSIDE ANIMAL PRODUCTION FACILITIES: A LITERATURE REVIEW
}

\section{DINÁMICA DE FLUIDOS COMPUTACIONALES (CFD) $Y$ SU USO PARA ANALIZAR LA DISTRIBUCION DE GASES AL INTERIOR DE INSTALACIONES PECUARIAS: UNA REVISIÓN DE LITERATURA}

\author{
Flávio Alves Damasceno¹, Fernando da Costa Baêta², Marcio Arêdes Martins³, Jairo Alexander Osorio Saraz4, \\ Ilda de Fátima Ferreira Tinoco ${ }^{5}$
}

${ }^{1}$ Ingeniero Agrícola Engineer, PhD student - Universidad Federal de Viçosa - Brazil, flavio.damasceno@ufv.br, ${ }^{2}$ Profesor - Universidad Federal de Vicosa - Brazil, baeta@ufv.br, 3 Profesor - Universidad Federal de Vicosa - Brazil, aredes@ufv.br 4 Profesor - Universidad Nacional de Colombia - Sede Medellín, aosorio@unal.edu.co, 5 Profesora Universidad Federal de Vicosa - Brazil, iftinoco@ufv.br

Rev. U.D.C.A Act. E Div. Cient. 14(2): 83 - 93, 2011

\begin{abstract}
Currently, one of the most discussed subjects in commercial livestock production is the emission of gases and temperature distribution, associated to climate change and animal welfare, principally with gas as methane $\left(\mathrm{CH}_{4}\right)$ and ammonia $\left(\mathrm{NH}_{3}\right)$. Application of computational fluid dynamics (CFD) for predicting the occurrence of these gases, especially in the animal production sector, is becoming increasingly important. Along the years, the versatility, precision and ease of use offered by CFD has caused its greater acceptance by the agricultural and animal engineering community. Therefore, CFD is regularly utilized to solve environmental problems associated to climate control in commercial animal production installations. Due to a better combination between computational simulation in CFD and mathematical modeling, realism of these simulations has become more reliable in recent years. Based on these facts, the goal of this study was to showed the recent studies using commercial Computational Fluid Dynamics (CFD) to determinate the behavior and distributions of gases inside animal production installations, showing the advantages and limitations of the technique.
\end{abstract}

Key words: Computational models, mass and energy balance, animal production installation

\section{RESUMEN}

Actualmente, uno de los casos de mayor discusión en la producción animal, es la emisión de gases y de distribución de temperatura asociados al cambio climático y al comportamiento animal, principalmente con gases como metano $\left(\mathrm{CH}_{4}\right)$ y el amoniaco $\left(\mathrm{NH}_{3}\right)$. La aplicación de la dinámica de los fluidos computacionales (CFD) para predecir el comportamiento de esos gases, especialmente en el sector de producción animal, esta comenzando a ganar gran importancia. A lo largo de los años, la versatilidad, precisión y la facilidad de uso ofrecida por el CFD ha tenido una gran aceptación en la comunidad de la Ingeniería Agrícola y pecuaria en general. Por lo tanto, el CFD es regularmente utilizado para solucionar problemas ambientales asociados a control climático en instalaciones comerciales de producción animal. Debido a la mejor combinación entre la simulación computacional con CFD y modelos matemáticos, situaciones reales se han simulado con mayor confiabilidad en los últimos años. Este trabajo ofrece una revisión del estado del arte acerca de la aplicación de la técnica con CFD para determinar el comportamiento y distribución de gases al interior de instalaciones pecuarias, mostrando las ventajas y limitaciones de la técnica.

Palabras clave: Modelos computacionales, balance de masa y energía, instalaciones de producción animal. 


\section{INTRODUCTION}

Currently one of the most discussed subjects of commercial animal production is the emission of gases, mainly methane $\left(\mathrm{CH}_{4}\right)$ and ammonia $\left(\mathrm{NH}_{3}\right)$, associated with environmental and climatic changes. Until recently it was estimated that the annual global emissions totaled 689 million tons of $\mathrm{CH}_{4}$ (Moss et al. 2000) and 53.6 Mt of $\mathrm{NH}_{3}-\mathrm{N}$ (Bouwman et al. 1997), where $12.8 \mathrm{Mt}$ of $\mathrm{NH}_{3}-\mathrm{N}$ results from cattle manure and according to Watson et al. (1992), 80 and 25 million tons of $\mathrm{CH}_{4}$ are respectively emitted by enteric fermentation and animal manure.

References on the effects of the gases in animal production installations and its influence on animal health are often related to animal production in countries with temperate climates. In these locations, the constructions are completely closed and the final result of the production environment differs from Brazilian conditions, as well as the climatic factor to be considered (Miragliotta et al. 2002; Osorio et al. 2009).

According to Baêta $\mathcal{E}$ Souza (1997) and Osorio et al. (2009), the main air pollutants encountered in installations for animal production are ammonia $\left(\mathrm{NH}_{3}\right)$, carbon dioxide $\left(\mathrm{CO}_{2}\right)$, carbon monoxide $(\mathrm{CO})$, methane $\left(\mathrm{CH}_{4}\right)$, sulfur hydroxide $\left(\mathrm{H}_{2} \mathrm{~S}\right)$, nitrogen dioxide $\left(\mathrm{NO}_{2}\right)$ and dust. Thus, air quality in the animal production systems is directly related to the animals metabolism, liberating heat, moisture and $\mathrm{CO}_{2}$ to the atmosphere via respiration, as well as gases resulting from digestion of manure, including $\mathrm{NH}_{3}, \mathrm{CH}_{4}, \mathrm{H}_{2} \mathrm{~S}$, dust and gases from incomplete combustion from the heating system, such as $\mathrm{CO}$ and $\mathrm{NO}_{2}$.

Within the context of modern animal production, studies have shown that an inadequate production environment is one of the factors which may cause the development of respiratory diseases in birds (Miragliotta et al. 2002; Menegali et al. 2009) and swine (Nader et al. 2002; Sampaio et al. 2005; Silveira et al. 2009), however, few studies consider air quality in cattle confinements.

Both the microclimate and rate of gas emissions inside the installation are strongly influenced by the ventilation system. Understanding the interdependence between the ventilation system, the climate and the gas emission rate is a pre-requisite for the development of adequate ventilation systems.

Ventilation plays an important role in the renewal of air inside the installation, thus allowing a reduction in heat transfer area, facilitating body heat transfer by convection and evaporation, as well as reducing the excess moisture content and some gases such as $\mathrm{NH}_{3}, \mathrm{CO}_{2}$ and $\mathrm{H}_{2} \mathrm{~S}$ from the internal environment, resultant from the bedding, reparation and manure, thus avoiding pulmonary diseases (Baêta \& Souza, 1997).

According to Mueller $\mathcal{E}$ Krause (2007) the development of ventilation projects and heating systems in animal installations is based on heat and mass balances. Thus, different sources of heat and mass inside an installation can be found, such as and animals, floor, wet areas, manure, and others. However, to solve the mass and energy balance equations, information regarding the characteristics of the installation, the animal species, the animal age, the management practices, the desired interior climate conditions and the actual exterior climatic conditions is necessary.

Development of mathematical models and application of computational simulations, based on Computational Fluid Dynamics (CFD) allow a time and cost reduction when developing and adapting these projects.

The models of heat, mass and momentum transfer, based on the CFD models, have been amply utilized in studies for evaluation of the behavior of climatic variables inside both vegetative and animal structures (Bjerg et al. 2002; Sun et al. 2002; Gebremedhin E Wu, 2003; Prueger et al. 2008; Norton et al. 2009).

These models permit the reduction in number of experiments and the improvement of installations, based on the validation of experimental data, making them increasingly important in the agricultural industry. This importance has grown significantly after overcoming the principal problems of this tool, such as precision in simulations and lack of equipment with large computational domains which have allowed a greater applicability of this technique in recent years.

Based on these facts, the objective of this study is to provide an overview for the application of Computational Fluid Dynamics (CFD) for studying mass transfer of greenhouse gases inside animal production installations.

\section{MATERIALS AND METHODS}

The objective of this study was done through a literature search of a recently theoretical documents, secondary sources, books, articles and journals, since 1990, thus enabling consolidate information on the theoretical basis and applications about of use of CFD in animal production.

The topics tried in this paper were chosen based on the main uses of the CFD, to improve and design animal facilities, in aspects like ventilation and gas control inside of the structures. 


\section{Mass balance and research methods}

Carvalho et al. (2008) claimed that in animal production facilities the mass balance of fluids (air + water) which enter $(+)$ and exit (-) each control volume (CV) may be expressed by equation 1 and as can be seen in figure 1 , where, $\dot{m}_{n e b}$

is the mass of water applied by misting, $\dot{m}_{i n f}, \dot{m}_{i}$ and $\dot{m}_{s}$ are the mass flows of air which infiltrate, enter and exit the

installation, respectively; and $\dot{m}_{p}$ and $\dot{m}_{d}$ are in mass production by the animal and waste respectively

$$
\dot{\mathrm{m}}_{i}+\dot{\mathrm{m}}_{\mathrm{inf}}+\dot{\mathrm{m}}_{\mathrm{neb}}+\dot{\mathrm{m}}_{\mathrm{d}}+\dot{\mathrm{m}}_{\mathrm{p}}-\dot{\mathrm{m}}_{\mathrm{s}}=0
$$

Analysis of the mass balance has been amply utilized to study the loss of feeds from livestock installations and manure management systems, through feed and fertilizers information (Sommer E Dahl, 1999; Garrison et al. 2001; Tyrrell, 2001). This review provides important information on all types of animal production systems, especially when evaluating multiple projects whose objective are the reduction of odor and all greenhouse gas emissions. Therefore, when quantifying the different modes of input and output of the installation, the final destination of each nutrient ( $\mathrm{N}$ and $\mathrm{C}$ ) can be more easily understood, giving greater importance to the different types of nutrient losses.

Sommer E Dahl (1999) utilized a mass balance to estimate $N$ losses caused by denitrogenification during composting of the bedding. In this study, all measurements were done in a dynamic chamber, where gas emissions were determined along with leaching of nutrients during composing. Based on their mass balances, $\mathrm{N}$ losses during composting due to leaching, ammonia emissions and denitrogenification were 5 to $19 \%$ in relation to the initial $\mathrm{N}$.

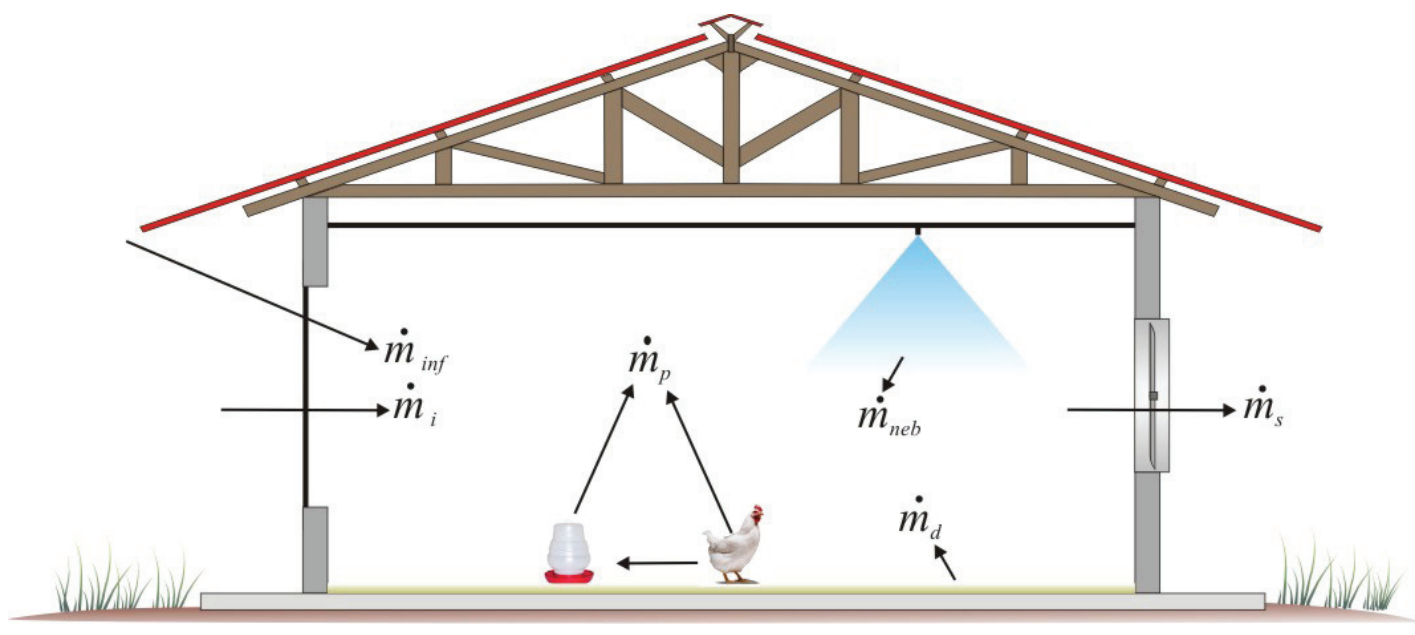

Figure 1. Main parameters used in the mass balance in animal facilities (adapted from Carvalho, 2008).

Teye E Hautala (2008) adapted a theoretical ammonia emission model for conditions of a naturally ventilated dairy cattle installation. For this purpose different mass transfer models were utilized and these were then evaluated experimentally. Also calculated were the mass balances of ammonia and carbon dioxide concentrations, directly measured in the installation. These authors concluded that the absolute mean difference and standard error between the ammonia emissions from the theoretical model and the experimental measurements was $0.013 \pm 0.05 \mathrm{~g} \mathrm{~m}^{-3} \mathrm{~h}^{-1}$. The variation in ammonia emissions during the day and night were 0.04 and $0.58 \mathrm{~g} \mathrm{~m}^{-3} \mathrm{~h}^{-1}$, respectively.
Michel et al. (2001) estimated $N$ and water losses via a mass balance, comparing a commercial High-Rise ${ }^{\mathrm{TM}}$ Hog Building (HRHB) with conventional deep pit systems. As a result, mass balance calculations based on the consumption of feed and level of protein for the finishing animals and $\mathrm{N}$ content of the deep pit effluent showed that 70 to $73 \%$ of the excreted $\mathrm{N}$, and $79 \%$ of the excreted water showed losses during accumulation of manure in the installation. These losses were probably due to volatilization of ammonia and evaporation of water due to the ventilation system.

According to Mueller $\mathcal{E}$ Krause (2007), when sizing ventilation systems there are different methods which may be used to 
obtain an overall view of the mass transport phenomena inside the animal production facility, including numerical simulation of flow, physical models and measurements on a real scale.

a) Numerical simulation of flow: from this simulation it is possible to study the behavior of fluids in movement. Therefore, it has become very interesting to study these phenomena with the advance of faster computer processors and more efficient software. Fluid mechanics include, for example, study of either laminar or turbulent fluid and gas flow in animal installations. This type of study may present important practical applications in the diverse areas of engineering. b) Physical models: investigations with physical models offer greater support to the numerical simulation of mass flux. The ventilation system as well as the flux of air volume may be altered by a simple formula, i.e., the reconstruction of entire elements may be performed quite simply in such models. Figure 2 a shows an example of a model for investigation of diverse methods of ventilation to reduce emission mass flows (Mueller E Krause, 2007).

c) Another form of evaluating the dispersion behavior of gases coming from animal installations is by means of the utilization of the wind tunnel boundary limit, which in many cases are equipped with air velocity sensors and

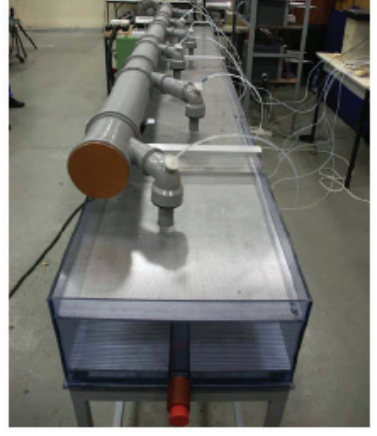

(a)

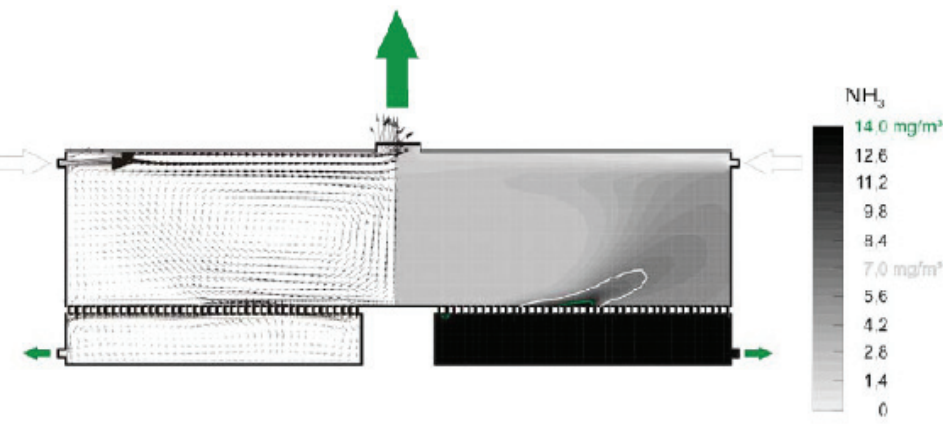

(b)

Figure 2. Physical model for (a) to study the emission of gases and their influence under different conditions of ventilation and (b) CFD simulation result in the behavior of the dispersion of ammonia in the wind tunnel boundary layer for plants in pigs (Mueller E Krause, 2007).

gas analyzers to measure the variation in concentration (Figure 2b).

d) Real scale measurements: are necessary to confirm the numerical and physical models in real conditions. A specific problem is the determination of volumetric air flux in naturally ventilated animal installations (Mueller $\mathcal{E}$ Krause, 2007).

Various studies involving mathematical modeling and computational simulations have been developed during experimentation to improve understanding on the processes involved in the transfer of heat and mass between animals and the thermal environment.

\section{CFD and the governing equations for transport of mass, momentum, energy and species}

Computational fluid dynamics (CFD) can be defined as a numerical resolution based on computational loops and the equations of mass, momentum and energy conservation for physical systems.

This technique provides precise solutions as well as visualizations of velocity, pressures, temperature, turbulence and gas concentrations in the entire space of the animal installation without various physical scale test models. Results allow engineers and operators to develop new ventilation strategies to meet the standards for air quality (Lee E Short, 2000). 
Modeling in CFD is important to predict mass transport in different types of animal structures, especially when measuring of the variables related to the model in the field is difficult. In the case of modeling gas emission present inside the installations, for example $\mathrm{NH}_{3}$, the computational models are based on the $\mathrm{NH}_{3}$ transport process and the transport mechanism to the atmosphere (Bjerg et al. 2002).

The governing equations of fluid flow and heat transfer can be considered as mathematical formulations of the laws of conservation which regulate all fluid flows, heat transfer and associated phenomena. These laws of conservation describe the rate of variation of a desired fluid property as a function of external forces and can be written as (Tu et al. 2007):

Continuity equation: the mass flows entering a fluid element must be equal to those exiting.

$$
\frac{\partial \rho}{\partial t}+\frac{\partial}{\partial x_{i}}\left(\rho u_{i}\right)=0
$$

Conservation of momentum: sum of the external forces acting on a fluid particle is equal to its variation in linear momentum.

$$
\begin{aligned}
& \frac{\partial}{\partial t}\left(\rho u_{i}\right)+\frac{\partial}{\partial x_{j}}\left(\rho u_{i} u_{j}\right) \\
= & \frac{\partial}{\partial x_{j}}\left[-p \delta_{i j}+\mu\left(\frac{\partial u_{i}}{\partial x_{j}}+\frac{\partial u_{j}}{\partial x_{i}}\right)\right]+\rho g_{i}
\end{aligned}
$$

Conservation of energy: the rate of energy variation of a fluid particle is equal to the addition of heat and work performed on the particle.

$$
\frac{\partial}{\partial t}\left(\rho C_{a} T\right)+\frac{\partial}{\partial x_{j}}\left(\rho u_{j} C_{a} T\right)-\frac{\partial}{\partial x_{j}}\left(\lambda \frac{\partial T}{\partial x_{j}}\right)=s_{T}
$$

Species conservation equation: if the viscous fluid is composed of a binary mixture in which there are species concentration gradients, relative transport of the species and species conservation must be satisfied in each point in the fluid.

$$
u \frac{\partial C_{A}}{\partial x}+v \frac{\partial C_{A}}{\partial y}=\frac{\partial}{\partial x}\left(D_{A B} \frac{\partial C_{A}}{\partial x}\right)+\frac{\partial}{\partial y}\left(D_{A B} \frac{\partial C_{A}}{\partial y}\right)
$$

\section{Ventilation system}

Ventilation systems are an efficient means of temperature control within animal installations by increasing thermal exchange by convection. Adequate ventilation is necessary to eliminate excess environmental humidity and bedding, resultant from water liberated by animal respiration and manures, as well as carbonic gases and gases resultant of fermentation (Abreu \& Abreu, 2000).

When considering ventilation, animal production installations may be open or closed. According to Zanolla et al. (1999), the acclimatization systems used in countries of Europe and the USA and also being adapted in Brazil, is known as tunnel ventilation. This system basically consists of the distribution of fans along the installation which suck in external air through a tunnel, permitting that the ventilated air mass uniformly passes through the entire building, exiting at the opposite end.

Therefore, in accordance with Norton et al. (2007), the modeled representation of a naturally ventilated installation in a computational domain with CFD models will allow a greater number of approaches, where the model may be constructed by:

a) Both internal and external regions of the installation, ventilated naturally;

b) Internal and external regions divided in subdomains and solved independently, interpolating the solutions and combining the interface regions;

c) Only the internal environment.

The first approach presents the advantage of directly connecting the internal and external environments. However, to perform this type of simulation a large computational force is needed due to the interlacing required for the shock between entering and exiting air. This may be aggregated by the large quantity of detail inside the installation, thus requiring a large computational time to conclude the simulation (Boulard et al. 2002).

The second method is not frequently encountered, although in some large scale simulations this technique is used, because the direct linking of the internal and external environments in the installation is not reached because of the lack of sufficient computational resources (Jiang \& Chen, 2001 and 2002). The last method has shown shortcomings in some cases, presenting many solutions, having no similarity with the physical flow regime (Fracastoro \& Perino, 1999).

Rarely have studies compared CFD models for animal installations with natural and forced ventilation. Due to the boundary conditions, where direction and velocity are not uniform along the installation at any moment in time, studies 
considering natural ventilation systems are more difficult to evaluate than those of installations with forced ventilation. Various studies conducted with natural and mechanical ventilation have utilized the turbulent flow model to simulate the linking of different models with the objective of obtaining better results.

Therefore, for systems with natural and forced ventilation, some studied recommend the use of the Standard k- $\varepsilon$ model to describe the turbulent portion of the flow (Bartzanas et al. 2004; Blanes - Vidal et al. 2008) due to its favorable convergence and reasonable precision. Some recent studies have shown better results using the Renormalization-Group (RNG) k- $\varepsilon$ model to simulate air movement inside and outside of the installations (Bartzanas et al. 2007; Stavrakakis et al. 2008; Seo et al. 2009), taking into consideration that the RNG k- $\varepsilon$ is similar to the Standard k- $\varepsilon$ model. However, the RNG k- $\varepsilon$ model includes additional terms for the development of dissipation rates which significantly improve its precision.

For mass balance simulations in animal installations, the turbulent flow model could be adapted based on the RANS models and concentration equations, together with the RNG k- $\varepsilon$ model (Lee $\varepsilon$ Short, 2000). Due to the high frequency and small scale fluctuations of turbulent flow, the instantaneous fluid velocity is the difficultly encountered and is often assumed to be the average velocity and a component of the velocity of turbulent fluctuation. The Reynolds tensions are assumed proportional to the average velocity gradients, adapting air as an ideal gas and coupling the fields of velocity and temperature, also known as the Bousssinesq approximation (Lee \& Short, 2000).

One of the limitations for the use of these equations for the simulation of the internal and external environment in animal installations is related to pressure conditions not being considered if the conditions of fluid velocity are too not specified, i.e., fluid velocity is influenced by the pressure gradient. The only exception is when the pressures are necessary to specify the fluid properties.

Another aspect to be considered in the CFD models of animal production installations is the air propulsion force, principally when working with natural ventilation systems or natural together with forced ventilation. According to Norton et al. (2007) two methods may be used: the Bousssinesq approximation, which has been intensely utilized in animal production applications; and the second method, in which the Bousssinesq approximation is an expression which treats air as an ideal gas and connects the fields of velocity and temperature; the first one is most commonly used.

Despite the importance of the propulsion forces, the majority of studies use the initial models without considering this aspect, and only when good results are not obtained is this condition introduced, which due to its numerical complexity makes convergence more difficult.

\section{CFD simulation for animal installations}

The first studies using livestock installations in CFD were performed by Choi et al. (1998), in which a simple geometry was employed to represent the animal installation, but results showed little precision. Small advances in the development of real solutions were made in the next year.

Hoff et al. (1992) utilized CFD to model air flow in a rectangular shaped installation, in which heat transfer was modeled using a heated floor. Harral $\&$ Boon (1997) simulated later isothermal flow patterns in a 3D geometric representation of a cattle confinement. In following years, more studies were developed for validation of animal installations with a focus on the creation of more precise CFD models (Zhang et al. 2000).

Only in recent years have CFD models, used for simulation of heat and mass transfer in a geometric representation, become reliable in animal production installations (Van Wagenberg et al. 2004). Therefore, when using dynamic models together with estimates provided by CFD, more detailed conditions are provided of all phenomena which occur.

\section{a) Birds}

Among environmental factors, thermal factors represented by air temperature, relative humidity, thermal radiation and air movement are those which most directly affect the bird since they are warm-blooded animals. These environmental variables may have either positive or negative effects on birds production. High temperature and high relative humidities inside aviculture installations are factors which limit the achievement of optimal productivity (Damasceno et al. 2010b). Therefore, the need to maintain the thermal environment within an optimal production scale is evident. However, there are few studies with CDF which utilize a mass balance inside aviculture installations.

Worley \& Manbeck (1995) utilized a CFD model to analyze the distribution of contaminants in a highly turbulent flow inside an aviculture installation under different roofing configurations. As a result this study obtained a better configuration of air circulation to eliminate particulate material with greater pollutions concentrations.

Pawar et al. (2007) compared relationship between diffusion of ammonia gas $\left(\mathrm{NH}_{3}\right)$ and dispersion of virus particles analyzing the distribution of virus particles which generate diseases in aviculture installations. In conclusion there is strong relationship between these parameters. 
Damasceno et al. (2010a) developed and validated a CFD model to analyze the temperature and air velocity distribution inside a common commercial heater used in Brazilian poultry production. These authors concluded that the CFD models may be used for real time prediction of thermal behavior and velocity distribution (inside the combustion chamber for heating), aiding in project improvements.

Tinôco et al. (2010) used CFD to simulate an aviculture installation with mechanical ventilation associated with an evaporative cooling system. In this study the authors developed a CFD model to obtain a better understanding of the temperature and air velocity distribution inside the aviculture installation. The obtained results showed a good statistical correlation with experimental data, which permits its use to address future modifications to the installation.

\section{b) Cattle}

The air quality conditions in a cattle confinement are dynamic and change continuously. Pollutant gases and excesses of humidity, microorganisms and particulate are produced from various sources, such as the floors, walls, feeds, water and air which infiltrates the installation. Therefore gas emissions directly depend on atmospheric influences which permanently change the conditions.

Various approaches to solve this problem have been studied. The quantification of carbon dioxide as well as mass and heat balances were performed by Van Ouwerkerk $\mathcal{E}$ Pedersen (1994) according to a method for calculating the concentration difference between interior and exterior air to determine the concentration levels.

Gebremedhin \& Wu (2003) utilized predictions based on CFD simulations to aid in modeling the thermal environment in dairy cattle installations. In their study, the Fortran computational program was used to calculate all models necessary for heat determination and mass transfer on the body of these animals. These authors thus used this method together with CFD simulations for heat and mass transfer between animals and the environment.

Gebremedhin \& Wu (2005) studied the utilization of CFD simulations for air flux in a simple geometric cattle installation with forced ventilation to investigate the heat and mass transfer phenomena. They discovered that the total heat loss of an animal is highly dependent on its position and orientation in the flow field. For example, a cow positioned near the air entrance may lose a total of $710 \mathrm{~W}$ of heat, while an animal positioned at the other extremity of the installation may lose only $214 \mathrm{~W}$ of heat.

\section{c) Swine}

Production and reproductive performance of swine depend on the employed management system, which involves the selected system of breeding, nutrition, sanity and the installations themselves. These installations, which demand a large initial investment, are constructed in function of the costs and facilities of the caretaker, often neglecting the comfort of the animals. Thus, many times the application of CFD models on the environment of these animals are directed towards the optimization of environmental conditions (Bjerg et al. 2000; Sun et al. 2002 and Sun et al. 2004). These studies may be efficiently grouped for modeling of pollutant dispersion and the thermal environment inside swine production installations.

\section{CONCLUSIONS}

The studies performed with Computational Fluid Dynamics (CFD) applied to understand the internal environment of animal installations aid in providing knowledge on the heat and mass and energy transfer phenomena, thus assisting to improve or design structures, reducing the time and cost for development and adaptation of projects.

One of the difficulties for CFD simulation of the internal and external environments of animal installations is the fact that fluid velocity is influence by the pressure gradient. Therefore, it is important to accompany the CFD models with experimental results which present good precision, since the results of the model depend largely on these experimental results.

Technological advances with CFD simulations have made it possible that field data may include dynamic biological responses to the encountered phenomena, thus improving the realism of the simulations. Therefore, CFD modeling may offer greater conditions of prediction for simulation of the internal environment of animal installations, giving greater decision making support to the producer, or even be implemented in system controllers for heating or cooling in commercial animal production installations, thus the gas emissions generated for different animals facilities production.

Acknowledgements: The authors wish to thank the producers for their participation in the study, and also FAPEMIG, CNPq, CAPES and the Department of Agricultural Engineering of at the Federal University of Viçosa for financial support. Conflicts of interest: The manuscript was presented and reviewed with the participation of all the authors who declare that there's not conflict of interest that threatens the validity of the results presented. 


\section{Nomenclature}

\begin{tabular}{|c|c|}
\hline$A$ & Area, $\left(\mathrm{m}^{2}\right)$ \\
\hline$C_{a}$ & Specific heat capacity, $\mathrm{W} \mathrm{kg}^{-1} \mathrm{~K}^{-1}$; \\
\hline $\mathrm{C}_{\mathrm{A}}$ & Concentration of species $\mathrm{A}$ in the gas, $\mathrm{g} \mathrm{m}^{-3}$ \\
\hline $\mathrm{D}_{\mathrm{AB}}$ & Diffusion coefficient between species $\mathrm{A}$ and $\mathrm{B}, \mathrm{m}^{2} \mathrm{~s}^{-1}$ \\
\hline$g$ & Acceleration of gravity, $\mathrm{m} \mathrm{s}^{-2}$ \\
\hline$u$ & Velocity vector, $\mathrm{m} \mathrm{s}^{-1}$; \\
\hline$i, j$ & Cartesian coordinate index, m; \\
\hline$\dot{m}_{n e b}$ & Mass of water applied by misting, , $\mathrm{m} \mathrm{s}^{-1}$; \\
\hline$\dot{m}_{\text {inf }}$ & Mass flows of air which infiltrate, $\mathrm{m} \mathrm{s}^{-1}$; \\
\hline$\dot{m}_{i}$ & Mass flows of air which enter, $\mathrm{m} \mathrm{s}^{-1}$; \\
\hline$\dot{m}_{s}$ & Mass flows of air which exit, $\mathrm{m} \mathrm{s}^{-1}$; \\
\hline$\dot{m}_{p}$ & Mass production of water vapor by the animal, $\mathrm{m} \mathrm{s}^{-1}$; \\
\hline$\dot{m}_{d}$ & Mass production of waste, $\mathrm{m} \mathrm{s}^{-1}$; \\
\hline$p$ & Pressure, $\mathrm{Pa}$ \\
\hline$T$ & Temperature, K; \\
\hline$t$ & Time, s; \\
\hline$S_{T}$ & Thermal dissipater or source, $\mathrm{W} \mathrm{m}^{-3}$; \\
\hline$x$ & Cartesian coordinate , m; \\
\hline \multicolumn{2}{|c|}{ Greek Symbols } \\
\hline$\lambda$ & Thermal conductivity, $\mathrm{W} \mathrm{m}^{-1} \mathrm{~K}^{-1}$; \\
\hline$\delta$ & Kronecker delta; \\
\hline$\mu$ & Dynamic viscosity, $\mathrm{kg} \mathrm{m}^{-1} \mathrm{~s}^{-1}$ \\
\hline$\rho$ & Density of the fluid, $\mathrm{kg} \mathrm{m}^{-3}$ \\
\hline \multicolumn{2}{|c|}{ Subscripts } \\
\hline$t$ & Turbulence; \\
\hline
\end{tabular}

\section{REFERENCES}

1. ABREU, P.G.; ABREU, V.M.N. 2000. Ventilação na avicultura de corte. Concórdia: Embrapa Suínos e Aves. 50p.

2. BAÊTA, F.C.; SOUZA, CF. 1997. Ambiência em edificações Rurais: conforto térmico animal. Viçosa, MG: UFV. 246p.

3. BARTZANAS, T.; KITTAS, C.; SAPOUNAS, A.A.; NIKITAMARTZOPOULOU, C. 2007. Analysis of airflow through experimental rural buildings: Sensitivity to turbulence models. Biosystems Engineering. 97(2):229-239.

4. BARTZANAS, T., BOULARD, T., KITTAS, C. 2004. Effect of vent arrangement on windward ventilation of a tunnel greenhouse. Biosystems Engineering. 88(1):479-490.
5. BJERG, B.; SVIDT, K.; ZHANG, G.; MORSING, S. 2000. The effect of pen partitions and thermal pig simulators on airflow in a livestock test room. J. Agr. Engineering Res. 77(2):317-326.

6. BJERG, B.; SVIDT, K.; ZHANG, G.; MORSING, S.; JOHNSEN, J.O. 2002. Modeling of air inlets in CFD prediction of airflow in ventilated animal houses. Computers and Electronics in Agriculture, 34(3):223235.

7. BLANES-VIDAL, V.; GUIJARRO, E.; BALASCH, S.; TORRES, A.G. 2008. Application of computational fluid dynamics to the prediction of airflow in a mechanically ventilated commercial poultry building. Biosystems Engineering. 100(1):105-116.

8. BOULARD, T.; KITTAS, C.; ROY, J.C. 2002. Structures and Environment: Convective and Ventilation 
Transfers in Greenhouses, Part 2: Determination of the Distributed Greenhouse Climate. Biosystems Engineering. 83(2):129-147.

9. BOUWMAN, A.F.; LEE, D.S.; ASMAN, W.A.H.; DENTENER, F.J.; VAN DER HOEK, K.W.; OLIVIER, J.G.J. 1997. A global high-resolution emission inventory for ammonia. Global Biochemical Cycles. 11(1):561-587.

10. CARVALHO, V.F.; YANAGI JR, T.; XIN, H.; GATES, R.S.; DAMASCENO, F.A.; MORAES, S.R.P. 2008. Mathematical Model for Thermal Environment and Broiler Chickens Performance Prediction in Acclimatized Housings. ASAE paper No 701P0408. Foz do Iguaçu, Brazil: ASAE.

11. CHOI, K.; ALBRIGHT, L.D.; TIMMONS, M.B. 1998. An application of the k-e turbulence model to predict air distribution in a slot ventilated enclosure. Transactions of the ASAE. 31(2):1804-1814.

12. DAMASCENO, F.A.; AMARAL, A.G.; MARTINS, M.A.; SARAZ, J.A.O.; BAÊTA, F.C. 2010a. Dinâmica do fluido computacional para simulação da temperatura e velocidade do ar em sistema de aquecimento avícola. In: Congresso Brasileiro de Engenharia Agrícola, 38. 2010, Vitória. Anais. Vitória: Soc. Bras. de Eng. Agr.

13. DAMASCENO, F.A.; YANAGI JUNIOR, T.; LIMA, R.R.; GOMES, R.C.C.; MORAES, S.R.P. 2010b. Avaliação do bem-estar de frangos de corte em dois galpões comerciais climatizados. Ciência Agrotecnica, Lavras. 34 (2): 1031-1038.

14. FRACASTORO, G.V.; PERINO, M. 1999. Numerical Simulation of Transient Effects of Window Openings. In: Proceedings of First International One day Forum on Natural and Hybrid Ventilation, HybVent Forum'99, Sydney, Australia. 425p.

15. GARRISON, M.V.; RICHARD, T.L.; TIQUIA, S.M.; HONEYMAN, M.S. 2001. Nutrient losses from unlines bedded swine hoop structures and an associated windrow composting site. ASAE paper No 01-2238. St. Joseph, Michigan: ASAE. 13-24.

16. GEBREMEDHIN, K.G.; WU, B. 2005. Simulation of flow field of a ventilated and occupied animal space with different inlet and outlet conditions. Journal of Thermal Biology. 30(5):343-353.
17. GEBREMEDHIN, K.G.; WU, B.X. 2003. Characterization of flow field in a ventilated space and simulation of heat exchange between cows and their environment. J. Thermal Biol. 28(1):301-319.

18. HOFF, S.J.; JANNNI, K.A.; JACOBSON, L.D. 1992. Three-dimensional buoyant turbulent flows in a scaled model, slot-ventilated, livestock confinement facility. Transactions of the ASAE. 35(2):671-686.

19. HARRAL, B.B.; BOON, C.R. 1997. Comparison of predicted and measured air flow patterns in a mechanically ventilated livestock building without animals. J. Agr. Eng. Res. 66(2):221-228.

20. JIANG, Y.; CHEN, Q. 2002. Effect of fluctuating wind direction on cross natural ventilation in buildings from large eddy simulation. Building and Environment. 37(1):379-386.

21. JIANG, Y.; CHEN, E.Q. 2001. Study of natural ventilation in buildings by large eddy simulation. J. Wind Eng. Ind. Aerodyn. 89(13):1155-1178.

22. LEE, I.B.; SHORT, T. 2000. Two-dimensional numerical simulation of natural ventilation in a multi-span greenhouse. Transactions ASAE. 43(3):745-753.

24. MENEGALI, I.; TINÔCO, I.F.F.; BAÊTA, F.C.; CECON, P.R.; GUIMARÃES, M.C.C.; CORDEIRO, M.B. 2009. Ambiente térmico e concentração de gases em instalações para frangos de corte no período de aquecimento. Rev. Bras. Eng. Agr. Amb. 13(2):984990.

25. MICHEL, F.C. Jr.; PECCHIA, J.; SUN, H.; KEENER, H. 2001. Use of a High Rise building and composting to manage swine manure. Proceedings Addressing Animal Production and Environmental Issue (CD). North Carolina State University. Triangle Research Park, NC. Poster, 24.

26. MIRAGLIOTTA, M.Y.; NÄÄS, I.A.; BARACHO, M.S.; ARADAS, M.E.C. 2002. Qualidade do ar de dois sistemas produtivos de frango de corte com ventilação e densidade diferenciadas: estudo de caso. Eng. Agr. 22(2):1-10.

27. MOSS, A.R.; JOUANY, J.P; NEWBOLD, J. 2000. Methane production by ruminants: its contribution to global warming. Ann. Zootechnie. 49(1):231-253. 
28. MUELLER, H.J.; KRAUSE, K.H. 2007. Flow simulation for design of ventilation systems in animal houses. Building Simulation, New York, p.932-936.

29. NADER, A.S.; BARACHO, M.S.; NÄÄS, I.A.; SAMPAIO, C.A.P. 2002. Avaliação da qualidade do ar em creche de suínos. In: Seminário Poluentes Aéreos e Ruídos em Instalações para Produção de Animais. Campinas. Anais. Campinas: UNICAMP. p.49-56.

30. NORTON, T.; GRANT, J.; FALLON, R.; SUN, D. W. 2009. Assessing the ventilation effectiveness of naturally ventilated livestock buildings under wind dominated conditions using computational fluid dynamics. Biosystems Eng. 103(1):78-99.

31. NORTON, T.; SUN, D.W; GRANT, J.; FALLON, R.; DODD; V. 2007. Applications of computational fluid dynamics (CFD) in the modelling and design of ventilation systems in the agricultural industry: A review. Bioresource Techn. 98(12):2386-2414.

32. OSORIO, J A.; TINOCO, F.F.; CIRO, H.J. 2009. Ammonia: a review about concentration and emission models in livestock structures. Dyna. 76 (158):89-99.

33. PAWAR, S.R.; CIMBALA, J.M.; WHEELER, E.F.; LINDBERG, D.V. 2007. Analysis of poultry house ventilation using computational fluid dynamics. Transactions of the ASABE .50 (4): 1373-1382.

34. PRUEGER, J.H.; EICHINGER, W.E.; HIPPS, L.E.; HATFIELD, J.L.; COOPER, D.I. 2008. Air-flow distortion and turbulence statistics near an animal facility. Atmospheric Environ. 42(3):3301-3314.

35. SAMPAIO, C.A.P; NAAS, I.A.; NADER, A. 2005. Gases e ruídos em edificações para suínos aplicação das normas NR-15, CIGR e ACGIH. Eng. Agr., Jaboticabal. 25(1):10-18.

36. SEO, I.H.; LEE, I.B.; MOON, O.K.; KIM, H.T.; HWANG, H.S.; HONG, S.W. 2009. Improvement of the ventilation system of a naturally ventilated broiler house in the cold season using computational simulations. Biosystems Engineering. 104(1):106-117.

37. SILVEIRA, N.A.; NAAS, I.A.; MOURA, D.J.; SALGADO, D.D. 2009. Ambiência aérea em maternidade e creche de suínos. Eng. Agr., Jaboticabal. 29(3):348-357.
38. SOMMER, S.G.; DAHL, P. 1999. Nutrient and carbon balance during the composting of deep little. J. Agr. Eng. Res. 74(1):145-153.

39. STAVRAKAKIS, G.M.; KOUKOU, M.K.;VRACHOPOULOS, M.G.; MARKATOS, E.N.C. 2008. Natural crossventilation in buildings: Building-scale experiments, numerical simulation and thermal comfort evaluation. Energy and Buildings. 40(9):1666-1681.

40. SUN, S.H.; KEENER, R.; STOWELL, R.; MICHEL, F.C. 2002. Two-dimensional computational fluid dynamics (CFD) modeling of air and ammonia distribution in a High-RiseTM Hog Building (HRHB). Transactions of the ASAE. 45(5):1559-1568.

41. SUN, S.H.; KEENER, H.; WEI DENG, R.; MICHEL, F.C. 2004. Development and validation of 3-d CFD models to simulate airflow and ammonia distribution in a high-rise ${ }^{\mathrm{TM}}$ hog building during summer and winter conditions. Agr. Eng. Internal: the CIGR J. Scient. Res. and Developm. 4(6):1121-1134.

42. TEYE, F.K.; HAUTALA, M.. 2008. Adaptation of an ammonia volatilization model for a naturally ventilated dairy building. Atmospheric Environ. 42(2):4345-4354.

43. TINÔCO, I.F.F.; OSORIO, J.A.S.; GATES, R.S.; DAMASCENO, F.A.; MARIN, O.L.Z. 2010. 3D-CFD modeling of a typical uninsulated and internal misting tunnel ventilated brazilian poultry house. ASAE paper No 1009150. St. Joseph, Pittsburgh: ASAE. p.35-42.

44. TU, J.; YEOH, G.H.; LIU, C. 2007. Approach. ButterworthHeinemann. 472p.

45. TYRRELL, H.F. 2001. Principles of animal nutrition and mass balance relative to nutrient management. Proceedings Addressing Animal Production and Environmental Issue (CD). North Carolina State University. Triangle Research Park, NC. 324p.

46. VAN WAGENBERG, A.V.; BJERG, B.; BOT, G.P.A. 2004. Measurements and simulation of climatic conditions in the animal occupied zone in a door ventilated room for piglets. Agr. Eng. Internal: The CIGR J. Scient. Res. and Developm. Manuscript BC 03020.

47. VAN OUWERKERK, E.N.J.; PEDERSEN, S. 1994. Application of the carbon dioxide mass balance method to evaluate ventilation rates in livestock buildings. In: Proc. XII World Congress on Agricultural Engineering, Milano, Italy. p.516-529. 
48. WATSON, R.T.; MEIRA FILHO, L.G.; SANHUEZA, E.; JANETOS, T. 1992. Sources and sinks. In: Houghton, J.T; Callander, B.A; Varney, S.K (eds). Climate Change. Cambridge University Press, Cambridge, UK. p.25-46.

49. WORLEY, M.S.; MANBECK, H.B. 1995. Modelling particle transport and air flow in ceiling inlet ventilation systems. Transactions of the ASAE. 38(1): 231-239.

50. ZANOLLA, N.; TINÔCO, I.F.F.; BAÊTA, F.C.; CECON, P.R.; MORAES, S.R.P. 1999. Sistema de ventilação em túnel e lateral na criação de frangos de corte com alta densidade. Rev. Bras. Eng. Agr. e Ambiental, Campina Grande. 3(3):361-366.

51. ZHANG, G.; MORSING, S.; BJERG, B.; SVIDT, K.; STROM, J. S. 2000. Test room for validation of airflow patterns estimated by computational fluid dynamics. J. Agr. Eng. Res. 76(3):141-148.

Recibido: Febreo 1 de 2011

Aceptado: Agosot 30 de 2011 